\title{
New thelodont (Agnatha) and possible chondrichthyan (Gnathostomata) taxa established in the Silurian and Lower Devonian of the Canadian Arctic Archipelago
}

\author{
Tiiu Märss ${ }^{\mathrm{a}}$, Mark V. H. Wilson ${ }^{\mathrm{b}}$, and Raymond Thorsteinsson ${ }^{\mathrm{c}}$ \\ a Institute of Geology, Tallinn Technical University, Estonia pst. 7, 10143 Tallinn, Estonia; \\ marss@gi.ee \\ ${ }^{\mathrm{b}}$ Department of Biological Sciences and Laboratory for Vertebrate Paleontology, University of \\ Alberta, Edmonton, Alberta T6G 2E9, Canada; mark.wilson@ualberta.ca \\ ${ }^{c}$ Geological Survey of Canada, 3303 33rd Street, N. W. Calgary, Alberta T2L 2A7, Canada; \\ rathorst@NRCan.gc.ca
}

Received 29 October 2001, in revised form 11 December 2001

\begin{abstract}
New vertebrate taxa of Silurian and Early Devonian age from the Canadian Arctic Archipelago are established. Diagnoses, type designations, and illustrations are given for 25 new species of thelodonts and 2 new species tentatively referred to chondrichthyans. In addition, 10 new genera, 6 new families, and 1 new order of thelodonts, and 1 new family and 2 new genera of possible chondrichtyans are established. Full monographic description of all available material will be published shortly.
\end{abstract}

Key words: Canadian Arctic, Silurian, Lower Devonian, thelodonts (Agnatha), chondrichthyans (Gnathostomata).

\section{INTRODUCTION}

Preliminary results of the IGCP Project 328 expedition of 1994 to BaillieHamilton and Cornwallis islands, Canadian Arctic Archipelago, have been published (Märss et al. 1998a; Märss \& Gagnier 2001; Blom et al. 2002) and reported at meetings of IGCP Project 406 "Circum-Arctic Lower-Middle Palaeozoic Vertebrate Palaeontology and Biostratigraphy" (see Märss et al. 1997, 1998b, 1998c, 1999; Blom et al. 1999; Wilson et al. 2000).

A comprehensive study of thelodonts and putative chondrichthyans that were collected in the Canadian Arctic Archipelago during the 1994 expedition, as noted above, and in earlier field investigations by one of us (R. T.) is nearing 
completion and will be published elsewhere. The material was collected from various localities of five islands in about the centre of the archipelago, namely Baillie-Hamilton, Cornwallis, Devon, Prince of Wales, and Ellesmere. The cumulative age range of the taxa is Late Llandovery, Silurian, up to the middle Lochkovian, Devonian. Articulated squamations as well as many isolated scales derived from acetic-acid residues of rock samples, allow establishment of 39 species ( 25 of which are new) of Thelodonti, distributed in 25 genera (10 new) and 16 families (6 new), along with 5 orders ( 1 new), as well as two new species that are provisionally classified as chondrichthyans. The new articulated squamations and large fragments of 10 thelodont taxa from the Canadian Arctic serve to decrease the parataxonomic nature of thelodont classification. The squamations of two new putative chondrichthyans provide us with the earliest evidence of body form of species assigned to this group.

At the present time two major studies, Handbook of Palaeoichthyology. Agnatha edited by H.-P. Schultze, Berlin, and Palaeontology of Russia and Adjacent Countries. Agnathans and Early Fishes edited by L. Novitskaya, Moscow, are near submission. In the systematic part of both works the results of our research on thelodonts from the Canadian Arctic have been taken into consideration to some extent. To allow inclusion of the new thelodont taxa from the Canadian Arctic in these works, to avoid numerous possible synonyms or nomina nuda in the literature, and to enable other researchers currently working with arctic microvertebrates to use these taxonomic names, we here validate the taxa described more fully in the monograph. Herein, new taxa are diagnosed, types are designated, and type localities and horizons as well as repositories of collections are indicated. Holotypes with numbers carrying the prefix UALVP are housed in the Laboratory for Vertebrate Paleontology, University of Alberta, Edmonton, while specimens with numbers having the prefix GSC are deposited in the Geological Survey of Canada, Calgary, Canada.

Localities, sections, and stratigraphic data for each species established on material from Baillie-Hamilton and the east coast of Cornwallis Island are given in Märss et al. (1998a). The localities and the biostratigraphy of the beds on the northeast coast of Cornwallis Island, as well as on Prince of Wales and Ellesmere islands, have been studied by one of us (R. T.).

\section{AGE OF BEDS WITH ARTICULATED MATERIAL}

Articulated specimens of thelodonts and possible chondrichthyans were collected from a single locality in the type section of the graptolitic Cape Phillips Formation on the northeast coast of Cornwallis Island where they occur throughout a $2 \mathrm{~m}$ interval of thinly-bedded argillaceous limestone (GSC locality C-26661; UTM Zone 15X, 457500E, 8393250N). Other associated fossils include anaspids, heterostracans, graptolites, eurypterids, nautiloids, and conodonts. The conodonts occur in a $4 \mathrm{~cm}$ interval in about the centre of the vertebrate-bearing interval. They have been identified by T. T. Uyeno who correlates them with the amorpho- 
gnathoides conodont Zone of the uppermost Llandovery or lowest Wenlock (GSC, Calgary, unpublished internal Paleontological Report No. 1-TTU-92). Among several poorly preserved species of graptolites is Cyrtograptus cf. insectus which suggests an early Sheinwoodian age. This is all but confirmed by well-preserved specimens of C. murchisoni (C-151166), index species of earliest Wenlock age, which occur $0.5 \mathrm{~m}$ stratigraphically below the vertebratebearing interval (identifications of graptolites by R. T.). About $1 \mathrm{~m}$ below C. murchisoni is the highest occurrence of C. sakmaricus in this particular section, marking the top of the Llandovery. The zone of Monograptus riccartonensis, which indicates a middle Sheinwoodian age, occurs $30.5 \mathrm{~m}$ above the $2 \mathrm{~m}$ vertebrate interval.

Class AGNATHA Cope, 1889

Subclass THELODONTI Kiaer, 1932

Order LOGANELLIIFORMES Turner, 1991 (= Loganiida Turner, 1991)

Family LOGANELLIIDAE Karatajūtè-Talimaa, 1997

Remarks. Two other names have been applied to this family (Loganiidae and Loganellidae), but both are invalid because they are based on generic names that are junior homonyms (Turner 1991; ICZN 1999, article 39). The family Loganelliidae is based on the valid type genus Loganellia Turner, 1991, and was first used, as the subfamily Loganelliinae, by Karatajūtè-Talimaa (1997).

Content. Loganellia Turner, 1991; Illoganellia gen. nov.

Stratigraphical range. Lower Silurian-Lower Devonian.

Genus Loganellia Turner, 1991

Type species. Thelodus scoticus Traquair, 1898.

Diagnosis. See Märss \& Ritchie 1998, p. 147.

Loganellia sulcata sp. nov.

Plate I, figure 1; Plate II, figure 1; Figure 1(a)

Derivation of name. Latin sulcata, f., meaning sulcate or grooved; in reference to hollows in posterior lower crown surface.

Holotype. GSC 117177, well preserved articulated specimen, anterior part of body in ventral? view, with anterior part of head missing, Pl. II, fig. 1; set of scales shown in Fig. 1(a).

Type locality and horizon. Thorsteinsson quarry, Cape Phillips, northeast coast of Cornwallis Island; Cape Phillips Formation, lower Sheinwoodian, Wenlock, Silurian. 
Diagnosis. Small Loganellia (holotype $9.3 \mathrm{~cm}$ long and $3.5 \mathrm{~cm}$ wide); paired pectoral fins present; single dorsal, anal, and caudal fins present; two long rows of scales of leading edges of fins in UALVP 43150 possibly belonging to ventral (= pelvic?) fins; scales small (trunk scales $0.35-0.55 \mathrm{~mm}$ long, $0.1-0.2 \mathrm{~mm}$ wide); area with oak-leaf-like scales at anterior end of body very short; all posterior scales elongate, with relatively wide anterior portion of crown; crown with pair of medial ridges and up to three ridges and furrows on each side; posterior lower crown surface with median and lateral ridge forming deeper hollow (pocket) on each side; base displaced anteriorly; anterior spur of medium length; histology of Loganellia type.

Remarks. On Pl. I, fig. 1 the typical base and lower crown surface are shown.

Loganellia prolata sp. nov.

Plate II, figure 2; Figure 1(b)

Derivation of name. Latin prolata, f., meaning elongated; in reference to the very elongated crowns of scales.

Holotype. GSC 117178, anterior 3/4 of body in dorsal? view, Pl. II, fig. 2; set of scales shown in Fig. 1(b).

Type locality and horizon. Thorsteinsson quarry, Cape Phillips, northeast coast of Cornwallis Island; Cape Phillips Formation, lower Sheinwoodian, Wenlock, Silurian.

Diagnosis. Medium-sized Loganellia, estimated length about $15 \mathrm{~cm}$; margins of head scales serrated; trunk scales extremely elongated (length $0.5-0.75 \mathrm{~mm}$, width $0.15-0.25 \mathrm{~mm}$ ); medial area higher and slightly convex, only one lower lateral area on each side; posterior extremity of crown possibly becoming slightly wider; lower crown surface smooth; histology of Loganellia type.

\section{Loganellia exilis sp. nov.}

Plate I, figure 2

Derivation of name. Latin exilis, f., meaning thin, slender; in reference to the shape of the crown of the scales.

Holotype. Trunk scale UALVP 44658, Pl. I, fig. 2.

Type locality and horizon. 96.5 m, BH-2-94 section, Baillie-Hamilton Island; Cape Phillips Formation, Homerian, Wenlock, Silurian.

Diagnosis. Loganellia with strongly elongate trunk scales, length : width ratio up to 4.5; crown with three distinct areas nearly of same width and on same level, or with lateral areas slightly lower than median area but rising posteriorly; median area with two shallow ridges separated by longitudinal furrow; each lateral 

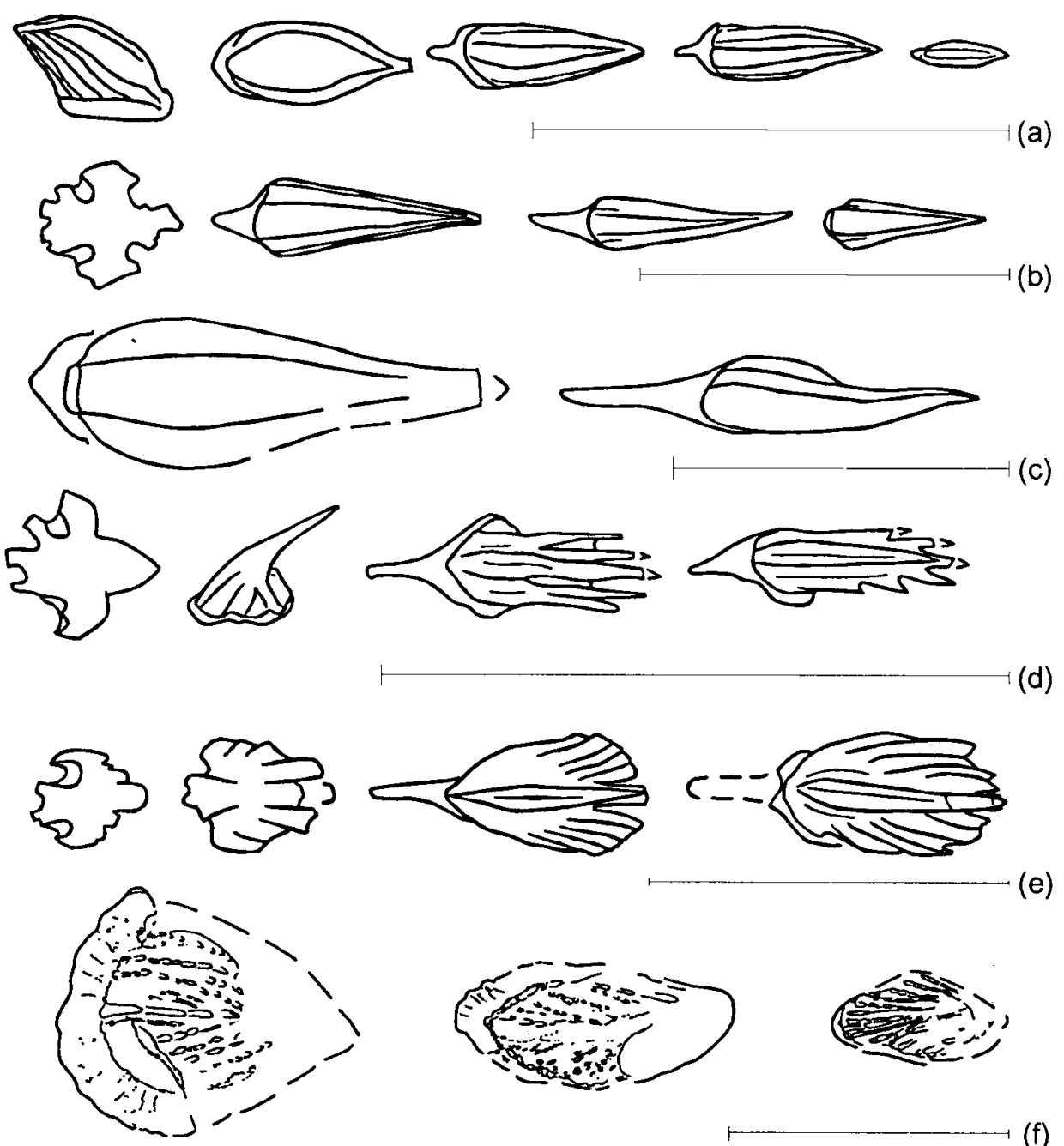

(e)

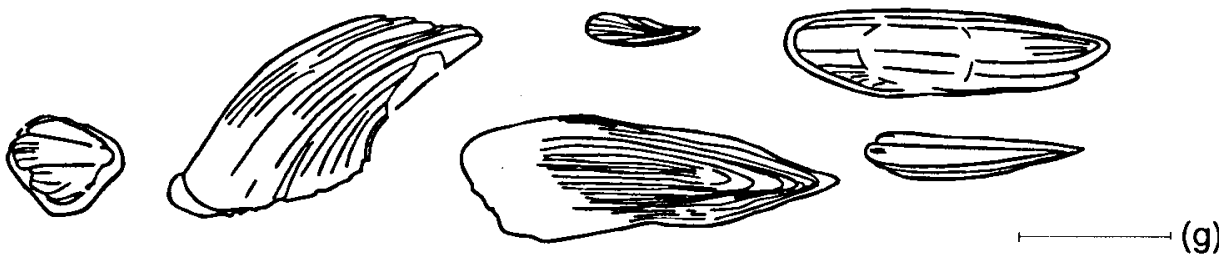

Fig. 1. Sets of selected scales drawn from the articulated specimens of holotypes. Scale bar beneath each set equals to $1 \mathrm{~mm}$. (a) Loganellia sulcata sp. nov., GSC 117177. (b) Loganellia prolata sp. nov., GSC 117178. (c) Illoganellia colossea gen. et sp. nov., UALVP 43129. (d) Shielia parca sp. nov., GSC 117179. (e) Shielia gibba sp. nov., GSC 117181. (f) Erepsilepis margaritifera gen. et sp. nov., UALVP 43115. (g) Phillipsilepis crassa gen. et sp. nov., GSC 117182. 

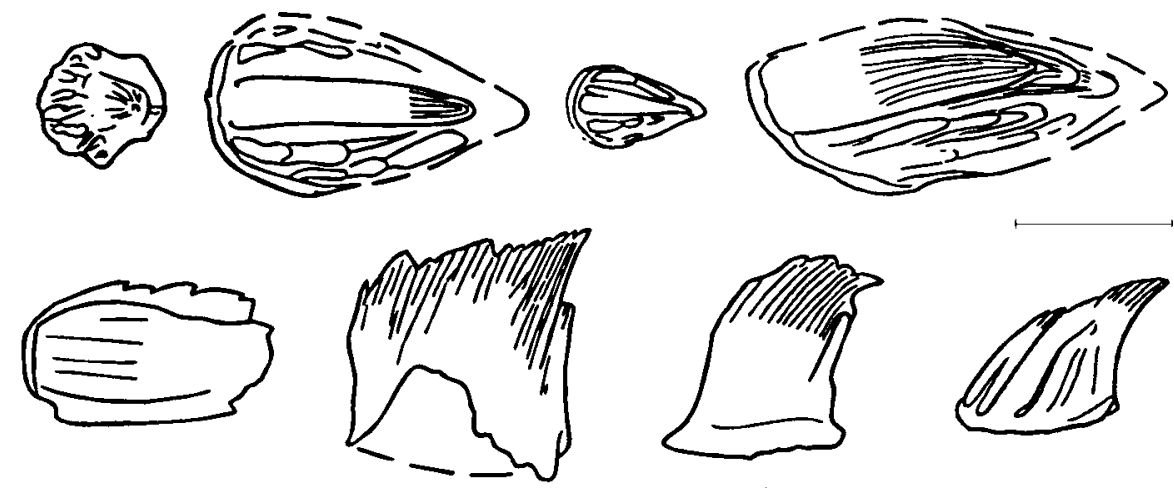

(h)
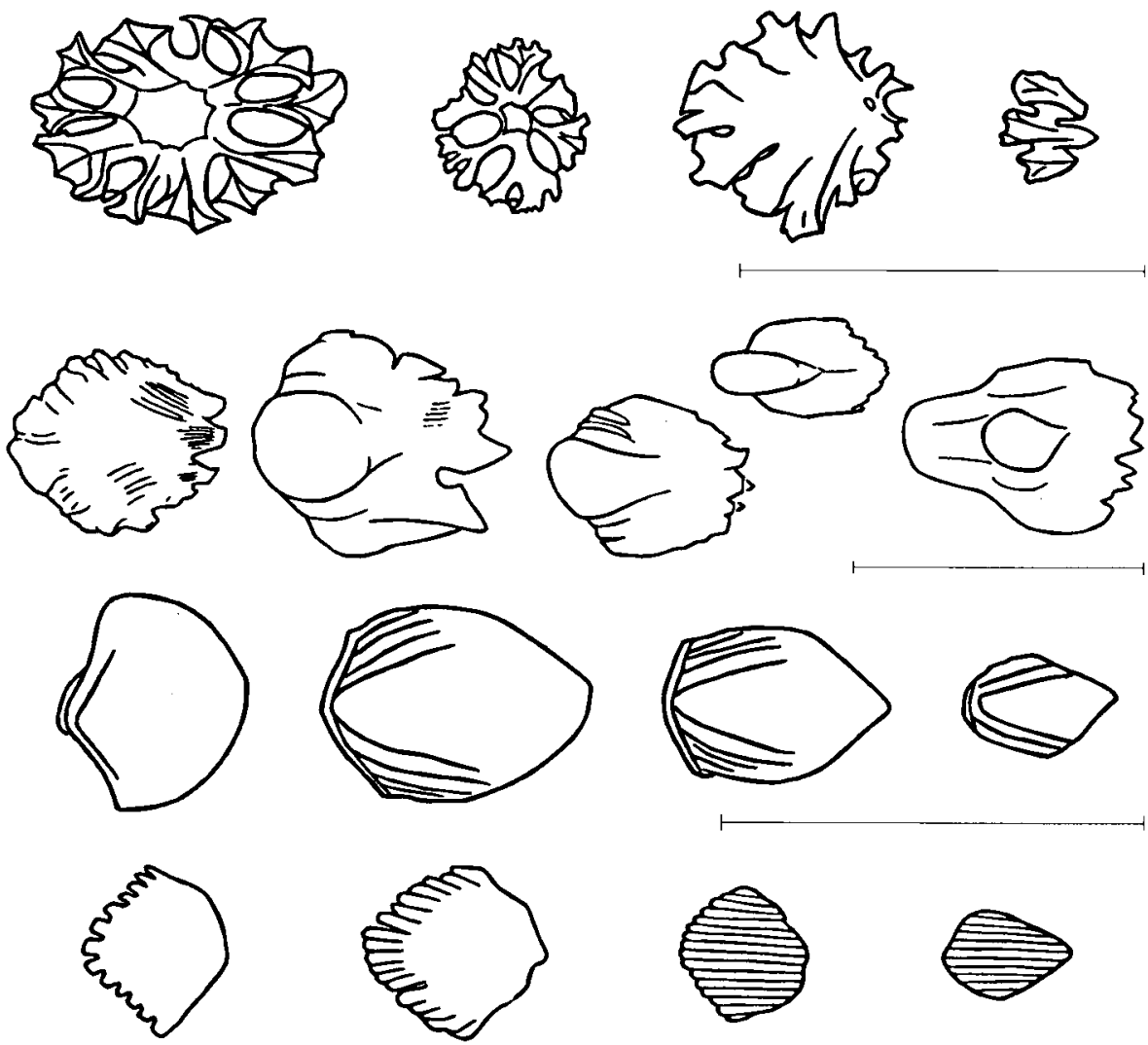

Fig. 1. Continued: (h) Phillipsilepis cornuta gen. et sp. nov., UALVP 43123. (i) Phillipsilepis pusilla gen. et sp. nov., GSC 117186. (j) Archipelepis bifurcata sp. nov., GSC 117187. (k) Eestilepis prominens gen. et sp. nov., GSC 117198. (1) Frigorilepis caldwelli gen. et sp. nov., GSC 117191. (m) Wellingtonella gagnieri gen. et sp. nov., GSC 117188.

All holotypes of articulated specimens come from the Thorsteinsson quarry, Cape Phillips, northeast coast of Cornwallis Island; Cape Phillips Formation, lower Sheinwoodian, Wenlock, Silurian. 
area with one ridge at edge; crown extending posteriorly far beyond base; base anteriorly situated, vertically swollen or with short spur anteriorly; histology of Loganellia type.

Genus Illoganellia gen. nov.

Derivation of name. Prefix il-, meaning not, combined with generic name Loganellia; alluding to distinction between these scales and those of Loganellia; gender feminine.

Type species. Illoganellia colossea gen. et sp. nov.

Diagnosis. As for type species.

\section{Illoganellia colossea gen. et sp. nov.}

Plate II, figure 5; Figure 1(c)

Derivation of name. From Latin adjective colossea, f., meaning giant; referring to large size of scales.

Holotype. UALVP 43129, patch of scales, Pl. II, fig. 5; set of scales shown in Fig. 1(c).

Type locality and horizon. Thorsteinsson quarry, Cape Phillips, northeast coast of Cornwallis Island; Cape Phillips Formation, lower Sheinwoodian, Wenlock, Silurian.

Diagnosis. Scales up to $1.5 \mathrm{~mm}$ long, two to three times larger than in Loganellia; scales elongate; crown of trunk scales arched in lateral view; median area smooth or with shallow furrow; lateral areas slightly lowered; base as elongate oval wall around pulp depression, higher posteriorly; scales of leading edges of fins? robust with higher medial and anteriorly lowered lateral areas; dentine canals and tubules relatively straight and regular, uppermost enameloid layer thick.

Family NUNAVUTIIDAE fam. nov.

Type genus. Nunavutia gen. nov.

Diagnosis. As for type genus and species.

Content. Nunavutia gen. nov. only.

Genus Nunavutia gen. nov.

Derivation of name. After Nunavut, a Territory for the Innuit people in northern Canada; gender feminine.

Type species. Nunavutia fasciata gen. et sp. nov.

Diagnosis. As for type species. 
Nunavutia fasciata gen. et sp. nov.

Plate I, figure 3

Derivation of name. Latin fasciata, f., meaning striped, striated; in reference to sculpture on crowns.

Holotype. UALVP 44741, scale, Pl. I, fig. 3.

Type locality and horizon. At $220.5 \mathrm{~m}$, BH-2-94 measured section, BaillieHamilton Island; Cape Phillips Formation, Gorstian, Ludlow, Silurian.

Diagnosis. Scales small, elongate, very thin, fragile; restored scale length up to $1.0 \mathrm{~mm}$, width up to $0.65 \mathrm{~mm}$; anterior margin of crown bluntly rounded; crown narrower anteriorly than at midlength; crown posteriorly elongate, narrowing smoothly towards tip; crowns covered with very fine longitudinal ridges and grooves; all ridges on crown either distributed rostro-caudally over scale and converging on single posterior point, or median ridges running straight to posterior end of crown but with more lateral ridges curving from base upwards and posteriorly; each fine ridge may be formed from two parallel finer ridgelets; lower crown surface smooth; neck as very narrow furrow; base rounded, anteriorly placed; anterior spur-like projection short or absent; pulp cavity large, continuing as wide pulp canal posteriorly.

\section{Order SHIELIIFORMES ordo novo}

Diagnosis. As for family Shieliidae (see below).

Content. Shieliidae (see below).

Family SHIELIIDAE fam. nov.

Type genus. Shielia Märss, 1998.

Diagnosis. Medium-sized (measured length $9.2-19.5 \mathrm{~cm}$ ) fusiform thelodonts; paired pectoral and ventral (= pelvic?) fins; single dorsal fin; hypocercal caudal fin, caudal fin "rays" absent; orbits on anterolateral corners of head surrounded by 2-3 rows of specialized, conical, high scales; scales of fin origin compact, relatively large; trunk scales with one median and up to eight posterior or posterolateral spines on crown; pulp cavity relatively large, shallow to deep; one median (= main) and up to eight lateral pulp canals corresponding to number of spines; dentine canals and tubules narrow, sinuous, branched.

Content. Shielia Märss, 1998; Paralogania Karatajūtè-Talimaa, 1997; Praetrilogania Blom, 1999.

Stratigraphical range. Lower Silurian to Lower Devonian. 


\section{Genus Shielia Märss, 1998}

Diagnosis. See Märss \& Ritchie 1998, p. 159.

Type species. Thelodus taiti Stetson, 1931.

Shielia parca sp. nov.

Plate II, figure 3; Figure 1(d)

Derivation of name. Latin parca, f., meaning scanty; in reference to paucity of spines of crown.

Holotype. GSC 117179, articulated specimen Pl. II, fig. 3; set of scales shown in Fig. 1(d).

Type locality and horizon. Thorsteinsson quarry, Cape Phillips, northeast coast of Cornwallis Island; Cape Phillips Formation, lower Sheinwoodian, Wenlock, Silurian.

Diagnosis. Small thelodonts (measured length $9.2 \mathrm{~cm}$ ) with very small to small scales (0.15-0.5 mm long); paired lateral, single dorsal and caudal fins present; head scales with wing-like lateral areas; trunk scales elongate and flattened; crowns with median smooth area or with pair of ridges separated by furrow, and with one to three flat lateral ridges ending posteriorly in long, free spines; medial pair of ridges converge posteriorly, lying on lower spine; base as wide as crown or narrower; anterior spur of base can be long.

Shielia gibba sp. nov.

Plate II, figure 4; Figure 1(e)

Derivation of name. Latin gibba, f., meaning humped, bent; in reference to convex nature of crown surface.

Holotype. GSC 117181, articulated specimen Pl. II, fig. 4; set of scales from it is in Fig. 1(e).

Type locality and horizon. Thorsteinsson quarry, Cape Phillips, northeast coast of Cornwallis Island; Cape Phillips Formation, lower Sheinwoodian, Wenlock, Silurian.

Diagnosis. Medium-sized thelodonts (holotype estimated length $19.5 \mathrm{~cm}$, width $5.9 \mathrm{~cm}$ ); paired pectoral fins; two other rows of scales of leading edges of fins in holotype possibly belonging either to dorsal and anal fins or to ventral (= pelvic?) fins; segments of rows of caudal fin preserved; scales small, $0.24-0.82 \mathrm{~mm}$ long; scale crowns with convex medial portion; spines numerous, two to seven but usually five, very narrow and long, closely situated on both sides of median area; latter flat or with pair of ridges; spines with smooth upper surface; each ridge 
supported on lower crown surface by one fine, vertical, longitudinal, narrow ridgelet; posteriorly pointed spines overhanging base; anterior projection long, spur-like, usually broken off; main and lateral pulp canals very fine; corresponding in number and extending through whole length of posterolateral spines.

Genus Paralogania Karatajūtè-Talimaa, 1997

Type species. Logania kummerowi Gross, 1967.

Diagnosis. See Karatajūtè-Talimaa 1997, p. 13.

\section{Paralogania readbayensis sp. nov.}

Plate I, figure 4

Derivation of name. Named after Read Bay, the type locality, on east coast of Cornwallis Island, Canadian Arctic.

Holotype. UALVP 44939, trunk scale, Pl. I, fig. 4.

Type locality and horizon. Talus at $61.5^{*} \mathrm{~m}$, southern Read Bay section, east coast of Cornwallis Island; Barlow Inlet Formation, Lower Lochkovian, Lower Devonian.

Diagnosis. Scales small (measured length up to $1.0 \mathrm{~mm}$ ); crown of trunk scales elongate, with relatively long posterior portion, with higher medial plate and downstepped lateral areas; median plate bent down, with short, shallow notch anteriorly, smooth and flat or slightly raised posteriorly; lateral crown areas with one to two longitudinal ridges of different height; usually one spine, rarely up to five, very short, anterior to ridges; lateral ridges joined behind and below posterior point of medial plate; base wider than crown, anterior spur directed either vertically, or anteriorly and downwards; pulp depression large, with rows of openings of dentine canals; pulp canal present; dentine canals proximally expanded and distally narrow.

Remarks. The Read Bay southern section consists of two parts (Märss et al. 1998a). The higher part is marked herein and below with an asterisk (*) following the measurement (height of sample) in metres.

\section{Order PHLEBOLEPIDIFORMES Berg, 1937 \\ Family PHLEBOLEPIDIDAE Berg, 1940}

Diagnosis. (Based mainly on articulated Phlebolepis and Erepsilepis). Small fusiform thelodonts; anterior part of cephalothorax dorsoventrally somewhat flattened; trunk behind pectoral fins narrowing slightly; paired pectoral fins, single dorsal and anal, and hypocercal caudal fin present; large, massive scales on fin 
origin absent; orbits lateral, behind anterolateral corners of head and surrounded by orbital platelets (= elongate large scales); sensory-line system represented by pores arranged in regular longitudinal rows with commissures between them (at least on Phlebolepis elegans Pander); scales small to large, covered with longitudinal or posteriorly converging ridges exhibiting spines or nodes, or else smooth; base as narrow wall, wide or deep rim bearing small, vertical, pearl-like swellings or anterior spur; several evenly distributed, wide dentine canals opening in wide shallow pulp depression; pulp canal short, if present.

Content. Phlebolepis Pander, 1856; Helenolepis Karatajūtè-Talimaa, 1978; Erepsilepis gen. nov.

\section{Genus Erepsilepis gen. nov.}

Derivation of name. Greek erepsis, roof, and lepis, meaning scale, gender feminine; name alluding to roof-like appearance of trunk scales.

Type species. Erepsilepis margaritifera gen. et sp. nov.

Diagnosis. As for type species.

\section{Erepsilepis margaritifera gen. et sp. nov.}

Plate III, figure 1; Figure 1(f)

Derivation of name. Latin margarita, pearl, and suffix -fera, f., meaning to bear; in reference to ornament of nodes on ridges of crown.

Holotype. UALVP 43115, articulated specimen Pl. III, fig. 1; set of scales shown in Fig. 1(f).

Type locality and horizon. Thorsteinsson quarry, Cape Phillips, northeast coast of Cornwallis Island; Cape Phillips Formation, lower Sheinwoodian, Wenlock, Silurian.

Diagnosis. Small thelodont, preserved specimens up to $4.3 \mathrm{~cm}$ long; caudal fin present; scales of medium size $(0.4-1.1 \mathrm{~mm}$ long), rhomboidal to oval; crown surface raised in middle of scale, roof-like; ridges, up to eight in number, directed from anterior to higher and wider longitudinal central ridge or sharp crest; ridges usually bearing rounded or elongate nodes, rarely smooth; base with very wide rim anterolaterally but becoming narrower posteriorly; pulp depression widely open.

\section{Family KATOPORODIDAE fam. nov.}

Type genus. Katoporodus Turner \& Peel, 1986.

Remarks. The family name Katoporidae Karatajūtè-Talimaa, 1970, has been applied to this group of thelodonts, but this name is invalid because it is based on 
a generic name that is a junior homonym (see Turner \& Peel 1986, p. 80). The family Katoporodidae fam. nov. is founded on the valid type genus Katoporodus Turner \& Peel, 1986 (ICZN 1999, article 39).

Diagnosis. Scales small to medium, with one medial and one to three lateral areas pointed posteriorly, or with longitudinal ridges converging posteriorly, or scales without posterior longer spines but with short spiny ridges; wide dentine canal openings distributed evenly or in three anteroposterior rows, or along posterolateral parts of base; one medial and up to three lateral pulp canals on each side of crown.

Content. Goniporus Gross, 1967; Katoporodus Turner \& Peel, 1986; Zuegelepis Turner, 1999; Overia Soehn, Märss, Caldwell \& Wilson, 2001.

Stratigraphical range. Lower Silurian to Lower Devonian.

Genus Katoporodus Turner \& Peel, 1986

Type species. Katoporus tricavus Gross, 1967.

Katoporodus serratus sp. nov.

Plate I, figures 5, 6

Derivation of name. Latin serratus, m., serrate; in reference to serrated lateral margins of crown.

Holotype. UALVP 44923, trunk scale Pl. I, fig. 5.

Type locality and horizon. At $34.5^{*} \mathrm{~m}$, southern Read Bay section, east coast of Cornwallis Island; Barlow Inlet Formation, Lower Lochkovian, Lower Devonian.

Diagnosis. Katoporodus with small to medium-sized monolithic scales (measured length up to $1.1 \mathrm{~mm}$ ), usually with serrated margins; scale crowns with one posterior apex; medial area of crown on same level as narrow lateral areas, or margins downstepped; pulp depression large (Pl. I, fig. 6) with single pulp canal opening; dentine canals wide, sinuous, branching; dentine tubules occurring only in uppermost part of crown.

\section{Katoporodus gemellus sp. nov.}

Plate I, figures 7, 8

Derivation of name. Latin gemellus, m., meaning double or twin; alluding to similarity of scales to those of another species of Katoporodus, namely K. lithuanicus Karatajūtè-Talimaa, 1978.

Holotype. UALVP 44709, trunk scale Pl. I, fig. 7.

Type locality and horizon. At $34.5^{*} \mathrm{~m}$, southern Read Bay section, east coast of Cornwallis Island; Barlow Inlet Formation, Lower Lochkovian, Lower Devonian. 
Diagnosis. Katoporodus with small to very small scales (length up to $0.55 \mathrm{~mm}$ ); general outline of trunk scales rhombic; crown as wide as long, with medial area and one to three lateral ridges; medial area flat and smooth or with two ridges separated by longitudinal furrow; lateral longitudinal ridges with sharp crests; posteriorly, lateral ridges forming outwardly-directed wing-like structures with serrated outer edges; ridges separated from each other anteriorly by grooves and posteriorly by slits (slits in K. lithuanicus wider and longer); base low, irregularly quadrangular, as wall around wide pulp depression; anterior spur-like process of base short to long; pulp canals one main and one to three lateral on each side.

Remarks. The most typical shape of scale in the samples is that shown as fig. 8 on Pl. I.

\section{Order THELODONTIFORMES Kiaer, 1932 \\ (= COELOLEPIDIFORMES Berg, 1937)}

Diagnosis. (Based on articulated Lanarkia, Phillipsilepis, Thelodus, Archipelepis, and Turinia). Small to large thelodonts (6 $\mathrm{cm}$ to 1(?) $\mathrm{m}$ long); head and anterior part of trunk wide, dorsoventrally flattened, posterior part of trunk and caudal fin laterally compressed; paired pectoral fins, single dorsal and anal fin, and hypocercal caudal fin present; caudal fin strongly heterocercal in young individuals, becoming nearly symmetrical in adults; orbits on anterolateral corners of head; scale morphology variable depending on position on body; pulp cavity single, occasionally continuing as pulp canal posteriorly; dentine tubules long, narrow, straight.

Content. Coelolepididae Pander, 1856; Lanarkiidae Obruchev, 1949; Turiniidae Obruchev, 1964; Apalolepididae Turner, 1976; Nikoliviidae Karatajūtė-Talimaa, 1978; Boothialepididae Märss, 1999; Archipelepididae Märss, 2001; Talivaliidae fam. nov.

Stratigraphical range. Lower Silurian to Upper Devonian.

Family COELOLEPIDIDAE Pander, 1856

Type genus. Coelolepis Pander, 1856.

Content. Thelodus Agassiz, 1838.

Stratigraphical range. Wenlock to Přidoli, Silurian.

Genus Thelodus Agassiz, 1838

Diagnosis. See Karatajūtè-Talimaa 1978, p. 99.

Type species. Thelodus parvidens Agassiz, 1839. 
Thelodus inauditus sp. nov.

Plate I, figure 9; Plate III, figure 3

Derivation of name. Latin inauditus, m., meaning new, unheard of; an allusion to the first occurrence of Thelodus in sediments as old as Early Wenlock.

Holotype. UALVP 43141, small patch of scattered scales on Pl. III, fig. 3; a scale shown on Pl. I, fig. 9.

Type locality and horizon. Thorsteinsson quarry, Cape Phillips, northeast coast of Cornwallis Island; Cape Phillips Formation, lower Sheinwoodian, Wenlock, Silurian.

Diagnosis. Scales small (length $0.45-0.65 \mathrm{~mm}$, width $0.4-0.55 \mathrm{~mm}$ ); crown margins smooth or crenulated, with very short and sharp marginal ridges; neck surface smooth, without vertical ridgelets; base up to three times height of crown; pulp opening situated posteriorly in base; most preserved bases of scales exhibit spur-like anterior process directed forward or forward and inward; microstructure of Thelodus type; dentine tubules varying from straight and fine, to rather wide in lower part of crown.

Family LANARKIIDAE Obruchev, 1949

Type genus. Lanarkia Traquair, 1898.

Revised diagnosis. (Based on articulated Lanarkia and Phillipsilepis). Small to medium-sized thelodonts; squamation composed of small scales with rows of larger scales between them; trunk scales medium to large, compact, high, conical or cockscomb-like; base as shallow rim; pulp depression or cavity large and deep; pulp cavity of trunk scales continuing as pulp canal into posterior tip of crown; dentine tubules fine, densely packed, simple and relatively straight in crown, sinuous in neck and anterior to base.

Content. Lanarkia Traquair, 1898; Phillipsilepis gen. nov.

Stratigraphical range. Lower Wenlock, Silurian.

Genus Phillipsilepis gen. nov.

Derivation of name. After Cape Phillips on northeastern Cornwallis Island where articulated specimens of genus are found, and lepis, meaning scale, gender feminine.

Type species. Phillipsilepis crassa gen. et sp. nov.

Diagnosis. Medium-sized thelodonts (measured maximum length $12.4 \mathrm{~cm}$, width $5.2 \mathrm{~cm}$ ); trunk scales medium to large (length up to $3.7 \mathrm{~mm}$ ), high, with cockscomb-like serrated crest, with fine ridges or rows of elongate short tubercles lateral to crown; base as oval, very shallow rim; pulp depression or pulp cavity deep; dentine tubules fine, simple, relatively straight, densely packed in crown, sinuous in neck and anterior to base. 


\section{Phillipsilepis crassa gen. et sp. nov. \\ Plate III, figure 2; Figure 1(g)}

Derivation of name. Latin crassa, f., meaning thick, fat; in reference to large size of scales, particularly those on leading edges of fins.

Holotype. GSC 117182, articulated specimen Pl. III, fig. 2; set of scales shown in Fig. 1(g).

Type locality and horizon. Thorsteinsson quarry, Cape Phillips, northeast coast of Cornwallis Island; Cape Phillips Formation, lower Sheinwoodian, Wenlock, Silurian.

Diagnosis. Medium-sized thelodonts, at least $12.4 \mathrm{~cm}$ long and $5.2 \mathrm{~cm}$ wide; caudal fin present; parallel rows (parts) of fin origin scales in GSC 117182 and 117183 seeming to belong to paired ventral fins; scales large, up to $3.7 \mathrm{~mm}$ long and $1.7 \mathrm{~mm}$ high; upper medial area of crown finely striated longitudinally; lateral narrow area on both sides smooth or with shorter striae posteriorly; crests of crowns cockscomb-like, serrated; neck indistinct; base oval, with very shallow and weak rim; pulp depression or pulp cavity deep; fine dentine tubules simple, relatively straight, densely packed in crown, sinuous in neck and anterior to base.

\section{Phillipsilepis cornuta gen. et sp. nov. \\ Plate IV, figure 5; Figure 1(h)}

Derivation of name. Latin cornuta, f., meaning bearing horns; in reference to short lateral ridges and horned crest of crown.

Holotype. UALVP 43123, large fragment of articulated specimen Pl. IV, fig. 5; set of scales shown in Fig. 1(h).

Type locality and horizon. Thorsteinsson quarry, Cape Phillips, northeast coast of Cornwallis Island; Cape Phillips Formation, lower Sheinwoodian, Wenlock, Silurian.

Diagnosis. Medium-sized thelodont (at least $8.8 \mathrm{~cm}$ long and $4.0 \mathrm{~cm}$ wide); trunk scales large (length up to $3.2 \mathrm{~mm}$ ); crown outwardly and posteriorly raised, with wide medial ridge bearing 1-4 strong horn-like structures; lateral ridges few, long or divided into shorter segments, or separate ridgelets.

Phillipsilepis pusilla gen. et sp. nov.

Plate III, figure 4; Figure 1(i)

Derivation of name. Latin pusilla, f., meaning very little, small; in reference to the small size and more fragile nature of its scales compared to those of the other two species. 
Holotype. GSC 117186, squamation missing anterior right cephalopectoral part, Pl. III, fig. 4; set of scales shown in Fig. 1(i).

Type locality and horizon. Thorsteinsson quarry, Cape Phillips, northeast coast of Cornwallis Island; Cape Phillips Formation, lower Sheinwoodian, Wenlock, Silurian.

Diagnosis. Medium-sized thelodont (at least $11.9 \mathrm{~cm}$ long and $4.4 \mathrm{~cm}$ wide); scales fragile, thin, up to $0.85 \mathrm{~mm}$ long and $0.8 \mathrm{~mm}$ high; trunk scales compressed laterally with high, medial, sharp crest having larger elevations, elevations in turn serrated; crown upper portion finely striated.

\section{Family ARCHIPELEPIDIDAE Märss, 2001}

Type genus. Archipelepis Märss, 2001, in Soehn et al. 2001.

Diagnosis. See Soehn et al. 2001.

Content. Archipelepis Märss, 2001, only.

Stratigraphical and geographical range. Upper Llandovery-Lower Wenlock, Lower Silurian of Mackenzie Mountains, and Cornwallis, Baillie-Hamilton, Devon, and Ellesmere islands.

Genus Archipelepis Märss, 2001

Type species. Archipelepis turbinata Soehn, Märss, Caldwell \& Wilson, 2001.

Diagnosis. See Soehn et al. 2001.

Archipelepis bifurcata sp. nov.

Plate I, figure 10; Plate IV, figure 1; Figure 1(j)

Derivation of name. Latin bifurcata, f., bifurcated; in reference to ornamentation of crowns, which show bifurcating ridges.

Holotype. GSC 117187, articulated specimen Pl. IV, fig. 1; set of scales shown in Fig. 1(j).

Type locality and horizon. Thorsteinsson quarry, Cape Phillips, northeast coast of Cornwallis Island; Cape Phillips Formation, lower Sheinwoodian, Wenlock, Silurian.

Diagnosis. Scales small; crown relatively low; most scale crowns wider than long (length $0.25-0.6 \mathrm{~mm}$, width $0.3-0.8 \mathrm{~mm}$ ); base length $0.25-0.8 \mathrm{~mm}$, width up to $1.1 \mathrm{~mm}$; ridges on crown two to four times bifurcated (Pl. I, fig. 10); grooves between ridges at crown margin deep and situated partly beneath ridges; neck distinct; base very deep, barrel-shaped or tetrahedral; height of base reaching 
$0.7 \mathrm{~mm}$, that of crown reaching $0.2 \mathrm{~mm}$, that of neck being about $0.1 \mathrm{~mm}$; pulp cavity deep or overgrown; pulp canal absent; dentine tubules simple, straight, distributed densely in crown, sparsely in neck and in upper part of base.

\section{Explanation of Plate I}

Figs. 1-19. SEM photographs of holotype scales and typical scales. All scales are in external view except 1, 6, and 12 which are in internal view, and 9 which is in lateral view. 1, Loganellia sulcata sp. nov., UALVP 44565, ×80; sample at $81.0 \mathrm{~m}$, BH-1-94 section; Cape Phillips Formation, Upper Telychian, Llandovery. 2, Loganellia exilis sp. nov., UALVP 44658, holotype, $\times 70$; sample at $96.5 \mathrm{~m}$, BH-2-94 section; Cape Phillips Formation, Homerian, Wenlock. 3, Nunavutia fasciata gen. et sp. nov., UALVP 44741, holotype, $\times 37$; sample at $220.5 \mathrm{~m}$, BH-2-94 section; Gorstian, Ludlow. 4, Paralogania readbayensis sp. nov., UALVP 44939, holotype, $\times 40$; talus at $61.5^{*} \mathrm{~m}$. 5, 6, Katoporodus serratus sp. nov., UALVP 44923, holotype, $\times 70$, and UALVP 44707, $\times 74$, respectively; sample at $34.5^{*} \mathrm{~m} .7,8$, Katoporodus gemellus sp. nov., UALVP 44709, holotype $\times 90$, and UALVP 45002, ×97; sample at $34.5^{*} \mathrm{~m}$, southern Read Bay section, Cornwallis Island; Barlow Inlet Formation, Lower Lochkovian. 9, Thelodus inauditus sp. nov., scale taken from the holotype UALVP 43141, $\times 62$; the Thorsteinsson quarry at Cape Phillips, northeast coast of Cornwallis Island; Cape Phillips Formation, lower Sheinwoodian, Wenlock. 10, Archipelepis bifurcata sp. nov., UALVP 44872, ×44; sample at 90.0 m, BH-1-94 section, Baillie-Hamilton Island; Cape Phillips Formation, middle Sheinwoodian, Wenlock. 11, 12, Nikolivia auriculata sp. nov., UALVP 44706, holotype, $\times 62$, and UALVP $44935, \times 65$; at $34.5^{*}$ and $42.0^{*} \mathrm{~m}$, respectively, southern Read Bay section, Cornwallis Island; upper part of Barlow Inlet Formation, Lower Lochkovian. 13, Chattertonodus cometoides gen. et sp. nov., UALVP 44743, holotype, $\times 78$; sample at $59.0 \mathrm{~m}$, southern Read Bay section, Cornwallis Island; Barlow Inlet Formation, Přidoli. 14, Glacialepis corpulenta gen. et sp. nov., UALVP 44969, holotype, $\times 64$; sample at $66.0 \mathrm{~m}$, northern Read Bay section, Cornwallis Island; Sophia Lake Formation, Lochkovian. 15, Canonia costulata sp. nov., UALVP 44912, holotype, $\times 80$; sample at $34.5^{*} \mathrm{~m}$. 16, Barlowodus excelsus gen. et sp. nov., UALVP 44687, holotype, $\times 122$; sample at $34.5^{*} \mathrm{~m}$. 17, Barlowodus floralis gen. et sp. nov., UALVP 44955 , holotype, $\times 70$; talus at $61.5 * \mathrm{~m} .18$, Barlowodus tridens gen. et sp. nov., UALVP 44700, holotype, $\times 77$; sample at $34.5^{*} \mathrm{~m}$, southern Read Bay section, Cornwallis Island; Barlow Inlet Formation, Lower Lochkovian. 19, Sophialepis ancorata gen. et sp. nov., GSC 117200 , holotype, $\times 100$; the GSC locality C-8234, Prince of Wales Island; Drake Bay Formation, middle Lochkovian, Lower Devonian. 20, Talivalia elongata (Karatajūtè-Talimaa), UALVP 44984, ×45; talus at $42.0^{*} \mathrm{~m}$, southern Read Bay section, Cornwallis Island; upper part of Barlow Inlet Formation, Lower Lochkovian. 21-23, photos of ultrasculpture on some scales: 21, Boothialepis thorsteinssoni Märss (UALVP 44723, ×105); 22, Canonia grossi Vieth (UALVP 44906, ×290); 23, Frigorilepis caldwelli gen. et sp. nov. (C-26661-S2, $\times 965)$.

\section{Explanation of Plate II}

Figs. 1-5. Holotypes of thelodonts, orders Loganelliiformes and Shieliiformes, known from articulated specimens. 1, Loganellia sulcata sp. nov., GSC 117177. 2, Loganellia prolata sp. nov., GSC 117178. 3, Shielia parca sp. nov., GSC 117179. 4, Shielia gibba sp. nov., GSC 117181. 5, Illoganellia colossea gen. et sp. nov., UALVP 43129. Scale bars equal to $1 \mathrm{~cm}$. All specimens come from the Thorsteinsson quarry at Cape Phillips, northeast coast of Cornwallis Island; Cape Phillips Formation, lower Sheinwoodian, Wenlock, Silurian. 
PLATE I
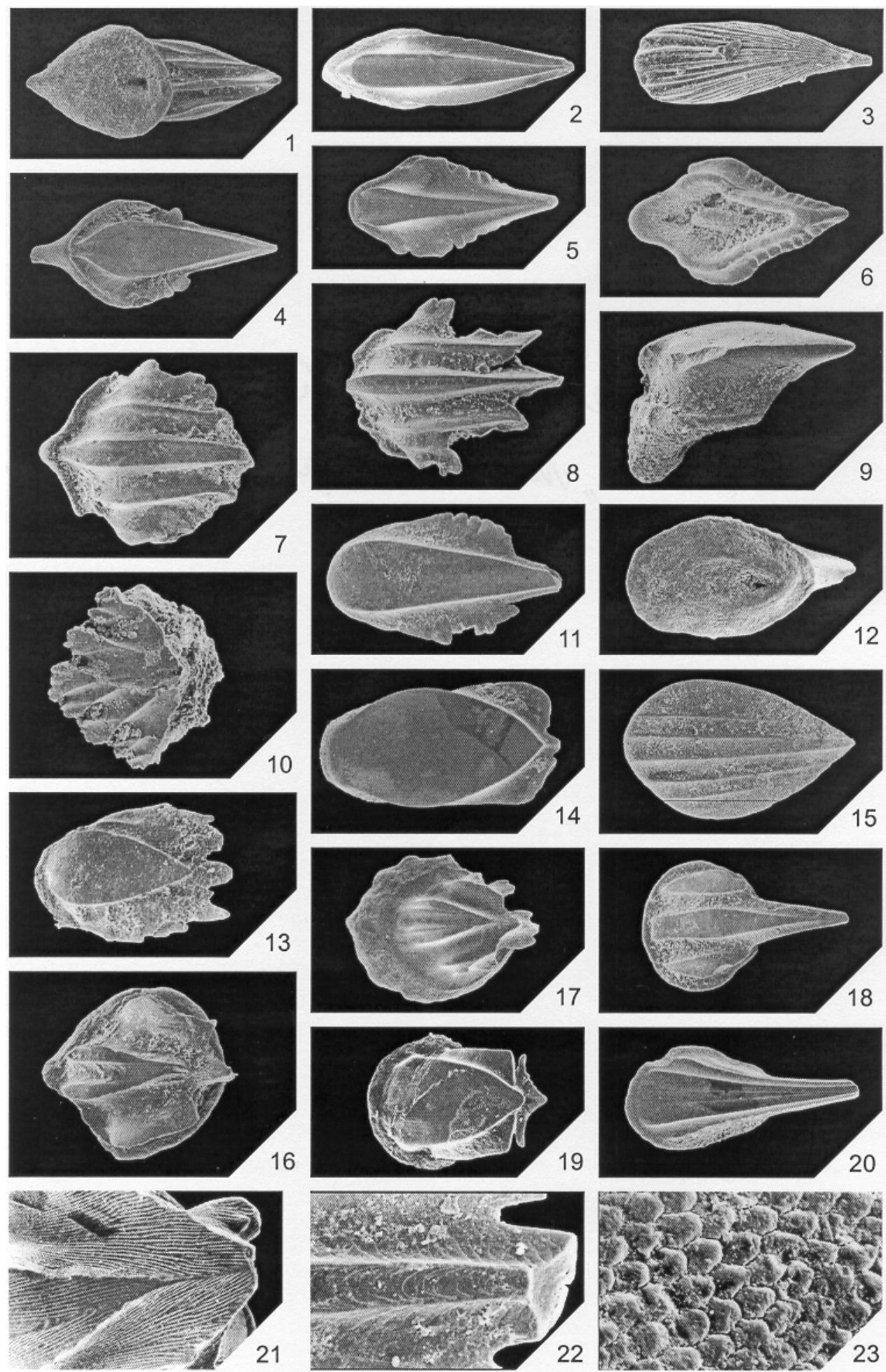


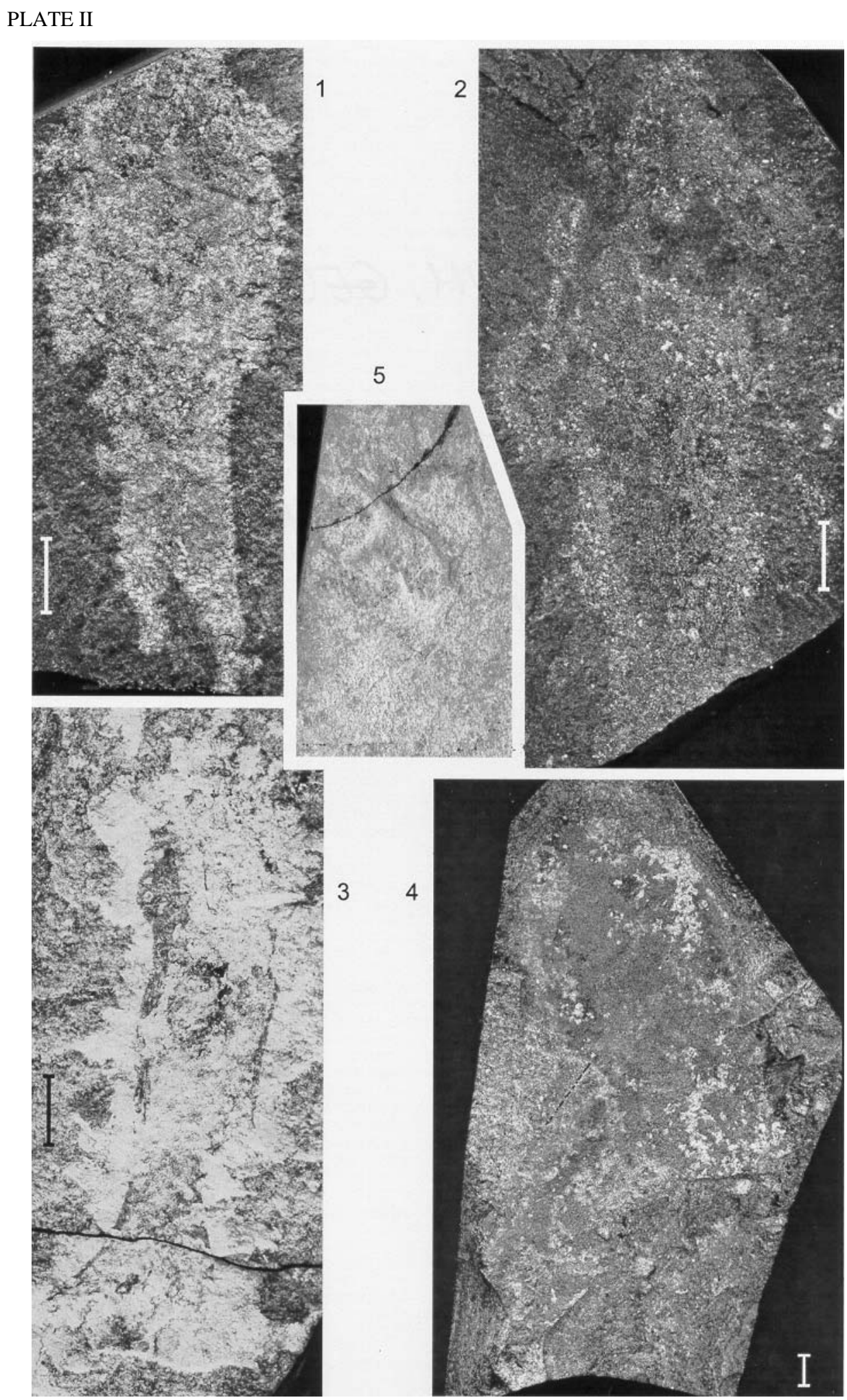


PLATE III
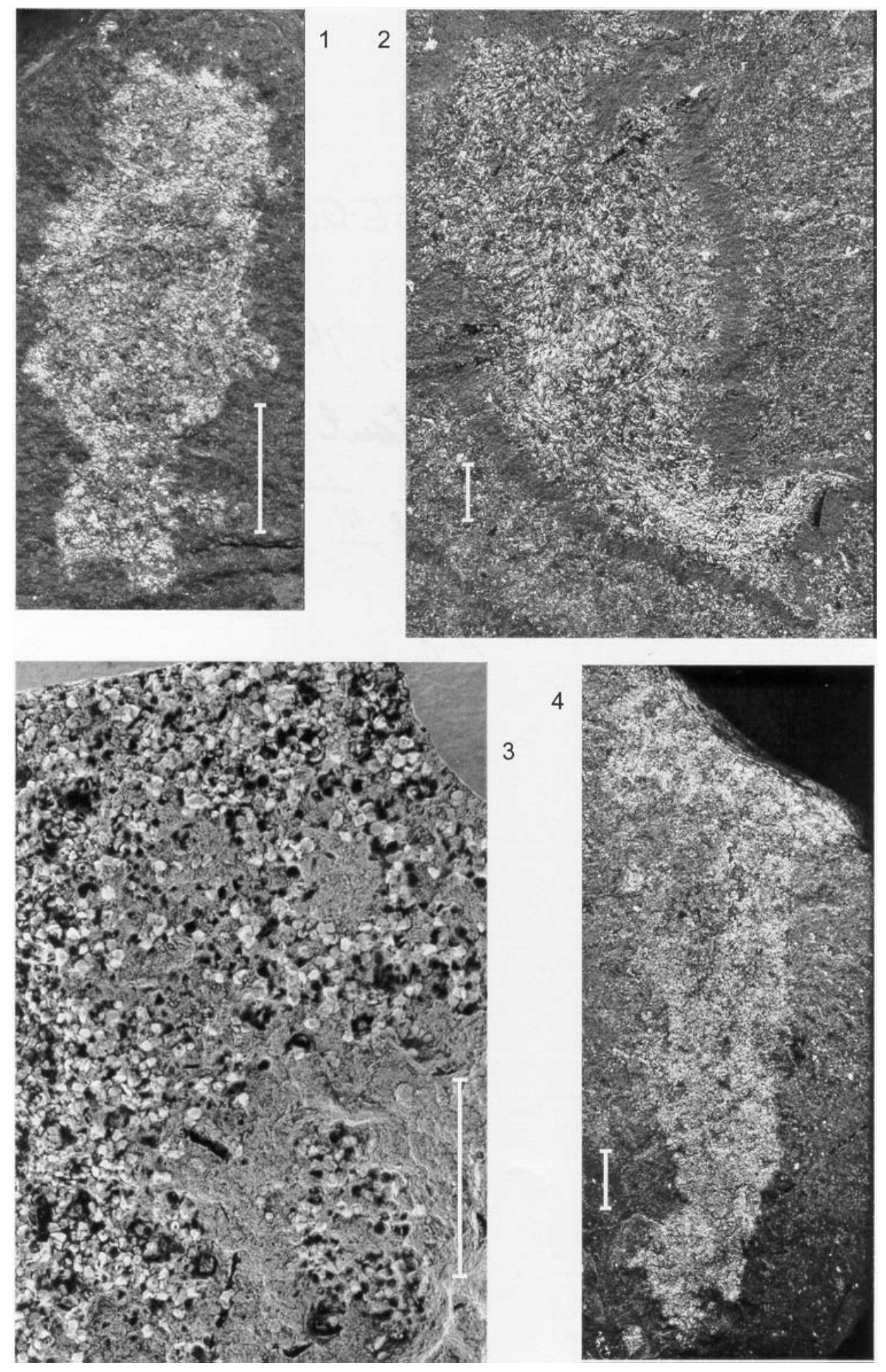
PLATE IV
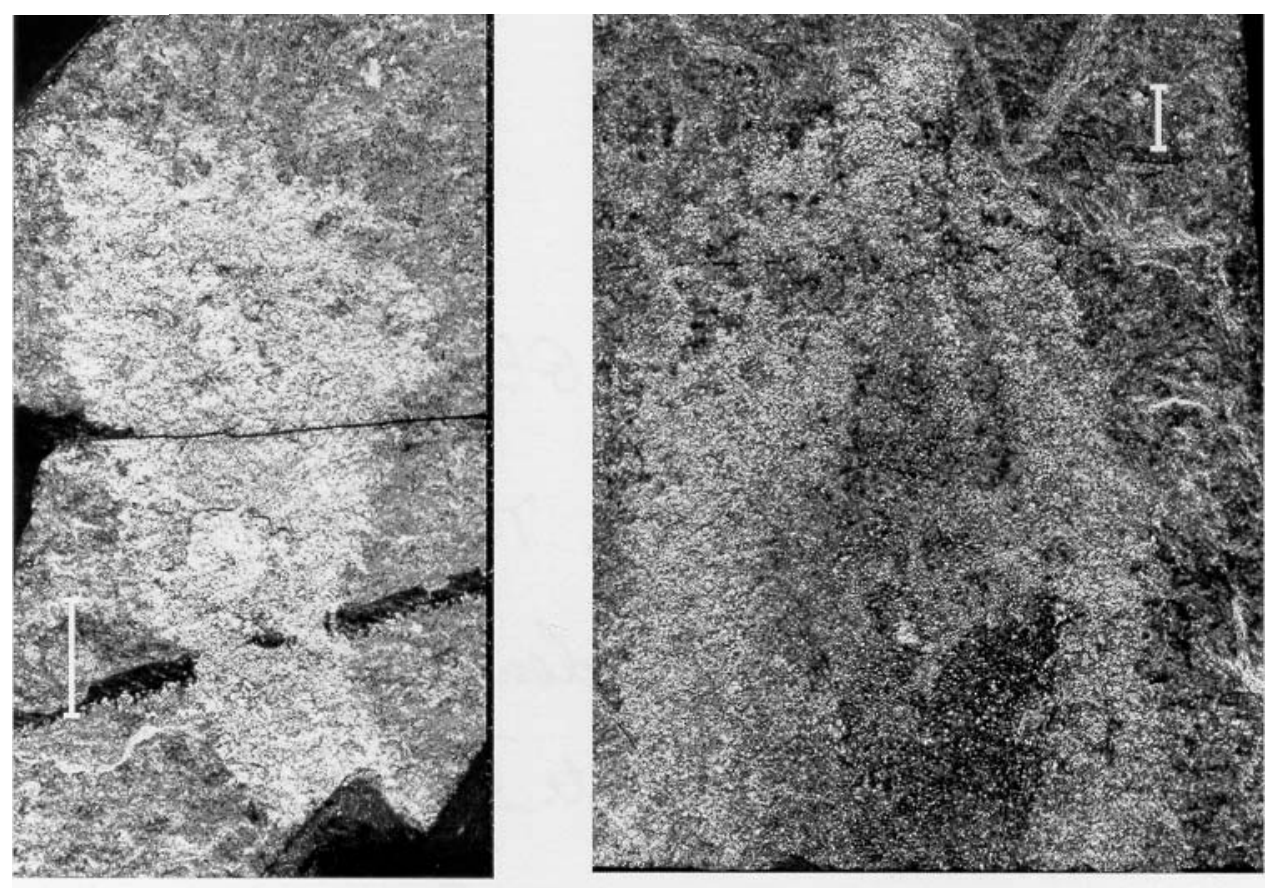

1

3

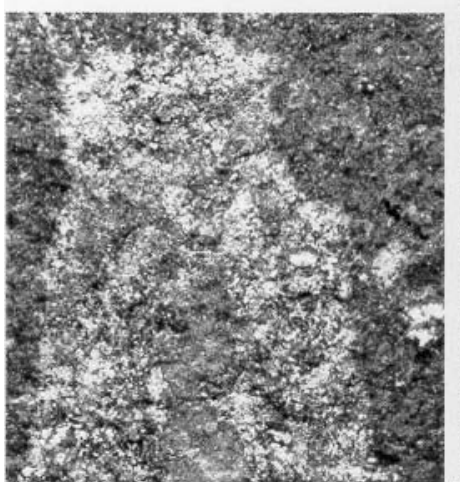

1.74.

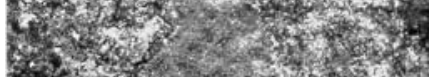

3.

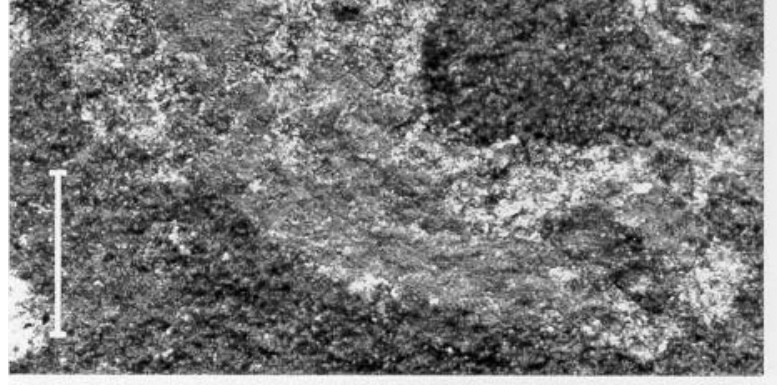

2

4

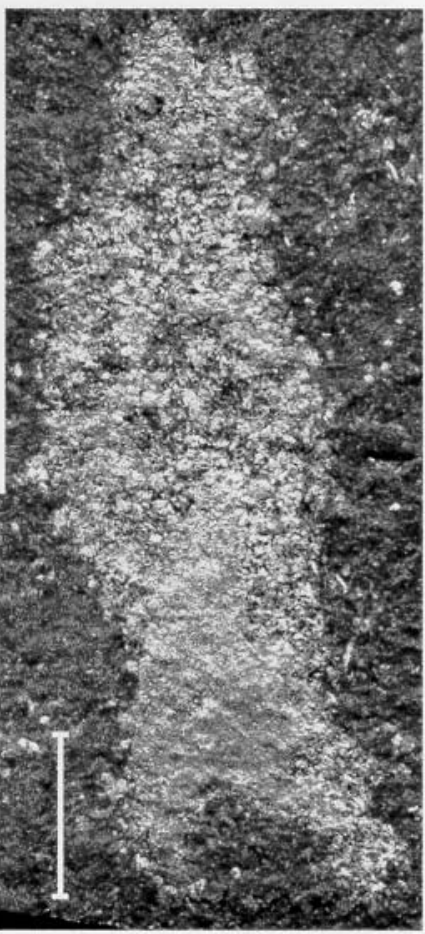




\section{Family NIKOLIVIIDAE Karatajūtè-Talimaa, 1978}

Diagnosis. (Based partly on a fragment of squamation of Nikolivia milesi; Turner 1982, p. 880). Medium-sized thelodonts; cephalothorax long with slim triangular pectoral flaps; scales small to medium-sized with spine-, keel-, lance- or leaf-like crowns with one to three posterior apices; base elliptical, relatively low, situated anteriorly; neck low, as distinct groove on posterior of scale but often indistinct on anterior; one large pulp cavity; short pulp canal sometimes present; dentine tubules usually very long, relatively narrow and straight; leading edges of fins covered with more robust and large scales.

Content. Nikolivia Karatajūtè-Talimaa, 1978; Chattertonodus gen. nov.

Stratigraphical range. From Přidoli, Silurian to Lochkovian, Lower Devonian.

Genus Nikolivia Karatajūtè-Talimaa, 1978

Type species. Thelodus oervigi Karatajūtè-Talimaa, 1968.

Diagnosis. See Karatajūtè-Talimaa 1978, p. 140 (excluding features of Nikolivia elongata Karatajūtè-Talimaa).

\section{Nikolivia auriculata sp. nov. \\ Plate I, figures 11,12}

Derivation of name. Latin auriculata, f., meaning ear-like; an allusion to lappetlike lateral areas of crown, which are very wide in some scales.

Holotype. UALVP 44706, scale Pl. I, fig. 11.

\section{Explanation of Plate III}

Figs. 1-4. Holotypes of thelodonts, orders Phlebolepidiformes and Thelodontiformes, known from articulated specimens. 1, Erepsilepis margaritifera gen. et sp. nov., UALVP 43115. 2, Phillipsilepis crassa gen. et sp. nov., GSC 117182. 3, Thelodus inauditus sp. nov., UALVP 43141. 4, Phillipsilepis pusilla gen. et sp. nov., GSC 117186 . Scale bars equal to $1 \mathrm{~cm}$. All specimens come from the Thorsteinsson quarry at Cape Phillips, northeast coast of Cornwallis Island; Cape Phillips Formation, lower Sheinwoodian, Wenlock, Silurian.

\section{Explanation of Plate IV}

Figs. 1-5. Holotypes of thelodonts, order Thelodontiformes, and of possible chondrichthyans known from articulated specimens. 1, Archipelepis bifurcata sp. nov., GSC 117187. 2, Eestilepis prominens gen. et sp. nov., GSC 117198. 3, Wellingtonella gagnieri gen. et sp. nov., GSC 117188 . 4, Frigorilepis caldwelli gen. et sp. nov., GSC 117191. 5, Phillipsilepis cornuta gen. et sp. nov., UALVP 43123. Scale bars equal to $1 \mathrm{~cm}$. All specimens come from the Thorsteinsson quarry at Cape Phillips, northeast coast of Cornwallis Island; Cape Phillips Formation, lower Sheinwoodian, Wenlock, Silurian. 
Type locality and horizon. At $34.5^{*} \mathrm{~m}$, southern Read Bay section, east coast of Cornwallis Island; upper part of Barlow Inlet Formation, Lower Lochkovian, Lower Devonian.

Diagnosis. Nikolivia with small to very small (length $0.3-0.5 \mathrm{~mm}$, width $0.2-$ $0.3 \mathrm{~mm}$ ) scales with posteriorly raised crown; medial and lateral crown areas distinct; medial plate rounded anteriorly and pointed posteriorly, smooth or with shallow furrow, separated from lateral lappets by wide, smooth furrows anteriorly and short slit posteriorly; lappets with serrated outer margins, situated at lower level; neck indistinct or lacking anteriorly, but occurring as shallow groove posteriorly; base of nikoliviid type, round or oval, low, open or infilled (Pl. I, fig. 12); pulp opening small, situated posteriorly in base; microstructure of rather narrow, straight or anteriorly bent dentine tubules.

\section{Genus Chattertonodus gen. nov.}

Derivation of name. Named after Dr. Brian Chatterton, Department of Earth and Atmospheric Sciences, University of Alberta, Edmonton, and Latin odus, m., meaning tooth.

Type species. Chattertonodus cometoides gen. et sp. nov.

Diagnosis. As for type species.

Chattertonodus cometoides gen. et sp. nov.

Plate I, figure 13

Derivation of name. Latin cometa, meaning comet, and suffix -oides, meaning like; an allusion to posterior extremity of scale which resembles the tail of a comet.

Holotype. UALVP 44743, scale Pl. I, fig. 13.

Type locality and horizon. At $59.0 \mathrm{~m}$, southern Read Bay section, east coast of Cornwallis Island; Barlow Inlet Formation, Přidoli, Upper Silurian.

Diagnosis. Scales small, wide, short, length $0.3-0.5 \mathrm{~mm}$, width $0.2-0.3 \mathrm{~mm}$; median plate anteriorly wide, smooth or ridged, shortened by downstepped lateral areas that join posteriorly beneath medial apex; lateral areas with spine posteriorly or whole posterior margin indented; neck distinct but low; base oval; anterior spur absent; histology not studied owing to insufficient material.

Family TALIVALIIDAE fam. nov.

Type genus. Talivalia gen. nov.

Diagnosis. Scales medium to large (length $1.0-3.0 \mathrm{~mm}$ ), longitudinally elongate, cuneiform, or high and spiny, with flat or ridged medial crown area and ridged 
or wing-like, lateral areas with one or several indentions; one to two parallel longitudinal ridges occurring on posterior lateral surface of crown; neck distinct; base rounded to oval, low; pulp cavity deep and continuing with one pulp canal; dentine tubules long, narrow and straight anteriorly in the crown, sinuous posteriorly.

Content. Talivalia gen. nov.; Glacialepis gen. nov.

Stratigraphical range. Lower Devonian.

Genus Talivalia gen. nov.

Derivation of name. After Dr. Valentina Talimaa, Vilnius, gender feminine.

Type species. Nikolivia elongata Karatajūtè-Talimaa, 1978.

Diagnosis. Medium-sized, elongate, keel-like scales (length up to $1.8 \mathrm{~mm}$ ); trunk scales elongate, wider anteriorly, crown rising posteriorly; crown with higher medial and lower lateral areas; sculpture consisting of longitudinal ridges and grooves: median area flat or convex, smooth; lateral areas (ridges) one to three in number, converging at posterior crown apex (Pl. I, fig. 20); base oval to rhomboidal, up to half as long as crown, situated anteriorly; pulp opening oval to slit-like; pulp canal present; dentine tubules long, narrow, straight to sinuous, opening into pulp cavity and canal.

\section{Genus Glacialepis gen. nov.}

Derivation of name. Latin glacialis meaning ice, and lepis, meaning scale, gender feminine; in reference to the locality in far north.

Type species. Glacialepis corpulenta gen. et sp. nov.

Diagnosis. As for type species.

Glacialepis corpulenta gen. et sp. nov.

Plate I, figure 14

Derivation of name. Latin corpulenta, f., meaning corpulent or stout; in reference to compact nature of crown and thick base of scales.

Holotype. UALVP 44969, scale Pl. I, fig. 14.

Type locality and horizon. At $66 \mathrm{~m}$, northern Read Bay section, east coast of Cornwallis Island; Sophia Lake Formation, Lower Lochkovian, Lower Devonian.

Diagnosis. Scales up to $1.0 \mathrm{~mm}$ long, elongate, rather high; crown consisting of medial plate and one, rarely two lateral downstepped ridges; medial plate smoothly rounded and curving inward to base, posteriorly horizontal, flat, smooth, ending with one keel-like apex; downstepped lateral ridges commencing 
farther posteriorly, ending blunt, wing-like, or converging at posterior crown apex; short slanting ridgelets present anteriorly to neck; base rounded to oval, displaced anteriorly; microstructure of long, narrow, straight dentine tubules; uppermost enameloid layer of crown relatively thick, with few, very narrow ends of dentine tubules.

\section{?Order THELODONTIFORMES Kiaer, 1932 \\ Family EESTILEPIDIDAE fam. nov.}

Type genus. Eestilepis gen. nov.

Diagnosis. As for type genus and only known species.

Content. Eestilepis gen. nov., only (see below).

Stratigraphical range. Wenlock, Silurian.

Genus Eestilepis gen. nov.

Derivation of name. After Eesti meaning Estonia, homeland of one author and member (T. M.) of expedition to Canadian Arctic islands in 1994, and lepis, meaning scale, gender feminine.

Type species. Eestilepis prominens gen. et sp. nov.

Diagnosis. As for type species.

Eestilepis prominens gen. et sp. nov.

Plate IV, figure 2; Figure 1(k)

Derivation of name. Latin prominens, f., meaning projecting or standing out; in reference to extremely high median area of crowns of scales.

Holotype. GSC 117198, anterior half of body most probably in dorsal view Pl. IV, fig. 2; set of scales shown in Fig. 1(k).

Type locality and horizon. Thorsteinsson quarry, Cape Phillips, northeast coast of Cornwallis Island; Cape Phillips Formation, lower Sheinwoodian, Wenlock, Silurian.

Diagnosis. Large thelodonts (anterior half of squamation of holotype at least $12.4 \mathrm{~cm}$ long and $8.2 \mathrm{~cm}$ wide); segments of scales of leading edges of fin belonging possibly to pectoral fin; scales small $(0.4-1.0 \mathrm{~mm}$ long, $0.3-0.8 \mathrm{~mm}$ wide); scale crown roundish, rhomboidal or oval, crown main surface flat to slightly convex or more often concave; median area roundish to oval anteriorly, strongly raised; anterior edge of trunk scales steeply bent downward, forming anterior part of neck and base; posterior margin of crown spiny; neck high; crown wider and longer than base. 


\section{Order FURCACAUDIFORMES Wilson \& Caldwell, 1998 \\ Family FURCACAUDIDAE Wilson \& Caldwell, 1998}

Diagnosis. See Wilson \& Caldwell 1998, p. 15.

Content. Furcacauda Wilson \& Caldwell, 1998; Cometicercus Wilson \& Caldwell, 1998; Drepanolepis Wilson \& Caldwell, 1998; Canonia Vieth, 1980.

Stratigraphical range. From Přidoli?, Silurian to Lochkovian, Lower Devonian.

\section{Genus Canonia Vieth, 1980}

Diagnosis. See Vieth 1980.

Type species. Canonia grossi Vieth, 1980.

\section{Canonia costulata sp. nov.}

Plate I, figure 15

Derivation of name. Latin costulata, f., meaning ribbed; in reference to finely ribbed surface of crown.

Holotype. UAL VP 44912, scale Pl. I, fig. 15.

Type locality and horizon. $34.5^{*} \mathrm{~m}$, southern Read Bay section, east coast of Cornwallis Island; upper Barlow Inlet Formation, Lower Lochkovian, Lower Devonian.

Diagnosis. Scales simple, small (length $0.3-0.37 \mathrm{~mm}$, width $0.2-0.28 \mathrm{~mm}$ ), rhomboidal, with flat crown surface, slightly bent down anteriorly; anterior margin of crown smoothly rounded, widest at midlength and tapered posteriorly to sharp median point; sculpture of 4-9 fine, sharp-crested, longitudinal ridges separated by low furrows; neck as relatively high and very thin wall, covered with fine striation posteriorly; base very low; pulp cavity deep; pulp canal short; dentine tubules in crown relatively simple, straight, narrow, branching on 3-4 levels, distributed subradially.

\section{?Order FURCACAUDIFORMES Wilson \& Caldwell, 1998}

Family BARLOWODIDAE fam. nov.

Type genus. Barlowodus gen. nov.

Diagnosis. Scales very small with very complicated crown sculpture; dentine tubules in crown relatively wide; base penetrated by very wide, strong, intrinsic and extrinsic fibre tubules (criss-crossed aspidine "pegs").

Content. Barlowodus gen. nov.; Sophialepis gen. nov.

Stratigraphic range. Přidoli?, Upper Silurian?, and Lochkovian, Lower Devonian. 
Genus Barlowodus gen. nov.

Derivation of name. From Barlow Inlet Formation, where the species of this genus occurs, and odus, meaning tooth, gender masculine.

Type species. Barlowodus excelsus gen. et sp. nov.

Diagnosis. Scales very small (length $0.19-0.5 \mathrm{~mm}$, width $0.13-0.4 \mathrm{~mm}$ ); scale crowns horizontal or rising posteriorly; crown with three flat ridges or system of bifurcating ridges separated by deep or wide grooves; posterior or posterolateral crown margin three- or multi-pointed; neck indistinct to distinct, low to relatively very high; base positioned centrally or displaced slightly anteriorly; base as narrow, shallow to deep wall around pulp cavity; dentine tubules in crown relatively wide; base penetrated by very wide, strong, criss-crossed aspidine "pegs".

\section{Barlowodus excelsus gen. et sp. nov.}

Plate I, figure 16

Derivation of name. Latin excelsus, m., meaning high, distinguished; because of scales with highest base and relatively high crown.

Holotype. UALVP 44687, scale Pl. I, fig. 16.

Type locality and horizon. At $34.5^{*} \mathrm{~m}$, southern Read Bay section, east coast of Cornwallis Island; upper part of Barlow Inlet Formation, Lower Lochkovian, Lower Devonian.

Diagnosis. Scales very small (length $0.19-0.32 \mathrm{~mm}$, width $0.13-0.2 \mathrm{~mm}$ ), relatively high (0.17-0.28 mm), longest axis vertical or angulated; ridges smooth and gently sloping, separated by wide grooves; medial area consisting of pair of bifurcating ridges separated by deep, short median groove; both lateral areas with wide, smooth, shallow groove and lateral downstepped ridge; ridges either smooth or with narrow furrows; posterior margin of crown with three points; neck distinct; base much wider than neck, rounded, as shallow or deep wall around rounded pulp cavity or pulp opening; pulp cavity continuing upwards as pulp canal; dentine tubules long, rising anterior to cavity or pulp canal, straight closer to base, curving knee-like posteriorly in middle portion of crown; strong criss-crossed aspidine "pegs" in base.

\section{Barlowodus floralis gen. et sp. nov.}

Plate I, figure 17

Derivation of name. Latin floralis, meaning of flowers; name prompted by aesthetically pleasing ornamentation of crowns of scales.

Holotype. UALVP 44955, scale Pl. I, fig. 17. 
Type locality and horizon. At $61.5^{*} \mathrm{~m}$, southern Read Bay section, east coast of Cornwallis Island; upper part of Barlow Inlet Formation, Lower Lochkovian, Lower Devonian.

Diagnosis. Scales small (length $0.3-0.5 \mathrm{~mm}$, width $0.2-0.4 \mathrm{~mm}$ ), rounded, oval or rhomboidal; crown usually narrower and shorter than base and extending slightly beyond base posteriorly; crown sculpture on rounded scales consisting of short, vertical ridges converging and joining at midpoint; crown of oval and rhomboidal scales with distinct medial and lateral areas, with four main, longitudinally arranged ridges and three main grooves uniting in posterior part of crown; medial area separated from lateral ones by wider longitudinal grooves; medial area always of bifurcated ridges; two to three posterolateral protuberances placed behind and beneath last ridge; one (single or double) protuberance beneath posterior crown apex; neck distinct as shallow groove; a few scale bases with notches related to lateral line canals; microstructure of relatively simple, straight dentine tubules in crown and strong and long aspidine "pegs" in base.

\section{Barlowodus tridens gen. et sp. nov.}

Plate I, figure 18

Derivation of name. Latin tridens, m., meaning three-toothed; a reference to crown terminating posteriorly in three pointed ridges.

Holotype. UALVP 44700, scale Pl. I, fig. 18.

Type locality and horizon. At $34.5^{*} \mathrm{~m}$, southern Read Bay section, Cornwallis Island; upper part of Barlow Inlet Formation, Lower Lochkovian, Lower Devonian.

Diagnosis. Scales very small, length up to $0.4 \mathrm{~mm}$ (mainly $0.3 \mathrm{~mm}$ ), width $0.15-0.3 \mathrm{~mm}$; crown with three smooth, flat, narrow, posteriorly pointed ridges, medial one usually longer than lateral ones; ridges lying horizontally or rising posteriorly, always on same plane, having steep lateral walls; neck as very narrow, shallow groove laterally and posteriorly, and indistinct anteriorly; base roundish or laterally wider, as oval wall around pulp depression; dentine tubules well developed in ridges; base penetrated by wide, strong, criss-crossed aspidine "pegs".

Genus Sophialepis gen. nov.

Derivation of name. From Sophia Lake Formation, where scales were found, and lepis, meaning scale, gender feminine.

Type species. Sophialepis ancorata gen. et sp. nov.

Diagnosis. As for type species. 


\section{Sophialepis ancorata gen. et sp. nov.}

Plate I, figure 19

Derivation of name. Greek ancora, meaning anchor, an allusion to the peculiar anchor-like structure beneath the posterior crown apex.

Holotype. GSC 117200, scale Pl. I, fig. 19.

Type locality and horizon. Sample from GSC locality C-8234, Prince of Wales Island (UTM Zone 14X, 427200E, 8150800N); Drake Bay Formation, middle Lochkovian, Lower Devonian, eurekaensis or delta conodont Zone as determined by T. T. Uyeno (GSC, Calgary, unpublished Internal Paleontological Report No. 9-TTU-75).

Diagnosis. Scales very small (length $0.20-0.35 \mathrm{~mm}$, width $0.15-0.25 \mathrm{~mm}$ ); crown oval, waterdrop-like or triangular, smooth, mainly flat; lateral rims downstepped, terminating posteriorly at right angle to long axis of scale; thin anchor-like structure lying posteriorly beneath crown; pulp opening large to small, rounded, situated posteriorly in base; pulp canal short, narrow, rising into posterior part of crown; dentine tubules very fine, extending from pulp canal radially towards crown sides; "anchors" with few dentine tubules; base criss-crossed by relatively wide aspidine "pegs".

\section{?Class CHONDRICHTHYES Huxley, 1880}

Subclass and order incertae sedis

?Family KANNATHALEPIDIDAE Märss \& Gagnier, 2001

Remarks. Features of Kannathalepididae include flat and low scale crown extending posteriorly far beyond base; gentle anterior sculpture; pentagonal and elongate ridged ultrasculpture; base usually wider than long; neck canals; dentine canals relatively wide and straight. The new genus below differs from Kannathalepis Märss \& Gagnier in having narrow dentine canals (or wide tubules?) that form loops; its ultrasculpture is different from Kannathalepis, and also from conventional thelodonts, e.g. Boothialepis thorsteinssoni Märss (see Pl. I, fig. 21) or furcacaudids, e.g. Canonia grossi Vieth, (see Pl. I, fig. 22), and formed only from scale-like polygons on flat crown surface (see Pl. I, fig. 23); neck canals absent.

\section{Frigorilepis gen. nov.}

Derivation of name. Latin frigus, meaning cold, and lepis, meaning scale, gender feminine; an allusion to climate of Arctic islands where specimens come from.

Type species. Frigorilepis caldwelli gen. et sp. nov.

Diagnosis. As for type species. 
Frigorilepis caldwelli gen. et sp. nov.

Plate I, figure 23; Plate IV, figure 4; Figure 1(l)

Derivation of name. After Dr. M. Caldwell, member of expedition to Canadian Arctic islands in 1994, and colleague at the University of Alberta, Edmonton.

Holotype. GSC 117191, articulated specimen in dorsal view, Pl. IV, fig. 4; set of scales shown in Fig. 1(1).

Type locality and horizon. Thorsteinsson quarry, Cape Phillips, northeast coast of Cornwallis Island; Cape Phillips Formation, lower Sheinwoodian, Wenlock, Silurian.

Diagnosis. Small fusiform vertebrates, holotype being at least $5.8 \mathrm{~cm}$ long and $1.9 \mathrm{~cm}$ wide; head exhibits possible orbits anteriorly; caudal fin present; scales small (up to $1.0 \mathrm{~mm}$ long, $0.7 \mathrm{~mm}$ wide), flat, low; crown rhomboidal to oval; crown surface flat; sculpture consisting of fine ridges commencing anteriorly on base and running upwards and towards lateral corners of crown; ultrasculpture on flat crown surface of pentagonal, scale-like fields; neck low; crown extending far beyond base posteriorly; base as rhomboidal rim, wider than long, anteriorly deeper than posteriorly; pulp cavity low; dentine canals rather wide at points of origin; dentine tubules posteriorly of crown forming unusual loops.

\section{Family WELLINGTONELLIDAE fam. nov.}

Type genus. Wellingtonella gen. nov.

Diagnosis. As for the type genus and species (see below).

Stratigraphical range. Wenlock, Lower Silurian.

Genus Wellingtonella gen. nov.

Derivation of name. After Wellington Channel situated east of Cornwallis Island where specimens of taxon originate, gender feminine.

Type species. Wellingtonella gagnieri gen. et sp. nov.

Diagnosis. As for type species.

Wellingtonella gagnieri gen. et sp. nov.

Plate IV, figure 3; Figure 1(m)

Derivation of name. After Dr. P.-Y. Gagnier, Paris, acanthodian expert and member of expedition to Canadian Arctic islands in 1994. 
Holotype. GSC 117188, well-preserved body squamation lacking caudal fin, Pl. IV, fig. 3; set of scales shown in Fig. 1(m).

Type locality and horizon. Thorsteinsson quarry, Cape Phillips, northeast coast of Cornwallis Island; Cape Phillips Formation, lower Sheinwoodian, Wenlock, Silurian.

Diagnosis. Small fusiform vertebrates (holotype $6.4 \mathrm{~cm}$ long, $2.2 \mathrm{~cm}$ wide); cephalothorax very long; orbits rather far behind anterolateral corners of head; caudal fin present; scales of only two different types, rostral and trunk; scales very small, $0.1-0.3 \mathrm{~mm}$ long, $0.1-0.3 \mathrm{~mm}$ wide; trunk scales strongly imbricated; crown of trunk scales rhomboidal to oval with relatively long posterior part; crown surface flat, finely ridged; base displaced far anteriorly; pulp opening very small; dentine tubules sparse in very small scales, sinuous, narrow.

\section{ACKNOWLEDGEMENTS}

This study was carried out mainly in the Institute of Geology at Tallinn Technical University and was supported by governmental target funding (project No. 033176s01) and Estonian Science Foundation (grant No. 4160). Work at the University of Alberta and in the field was supported by NSERC operating grant A9180 to M. V. H. Wilson and by the Canadian Polar Continental Shelf Project. A. Lindoe, M. Caldwell, P.-Y. Gagnier, and D. Goujet assisted with field work. V. Mikli made SEM photographs, G. Baranov prepared prints, and K. Ronk made figures. Colour images have been done by one of us (M. V. H. W.), and layout of plates and figures by U. Nurk. An anonymous referee and M. Rubel, University of Tartu, made valuable comments on the manuscript. The help of all the above mentioned people and institutions is gratefully acknowledged.

\section{REFERENCES}

Blom, H., Märss, T. \& Miller, C. G. 1999. Affinity, classification and distribution of Silurian and lowermost Devonian birkeniid anaspid scales in the Circum-Arctic, Baltoscandia and Britain. In Lower-Middle Palaeozoic Events Across the Circum-Arctic. Jürmala, Latvia, September 27-October 2, 1999 (Lukševičs, E., Stinkulis, G. \& Wilson, M. V. H., eds.). Icht. Iss. Spec. Publ, 5, 12-13.

Blom, H., Märss, T. \& Miller, C. G. 2002. Silurian and earliest Devonian birkeniid anaspids from the northern hemisphere. Trans. Roy. Soc. Edinburgh: Earth Sci., 92 (in press).

Gross, W. 1967. Über Thelodontier-Schuppen. Palaeontographica, A127, 1-67.

[ICZN] International Commission on Zoological Nomenclature. 1999. International Code of Zoological Nomenclature, 4th edn. International Trust for Zoological Nomenclature. London.

Karatajūtè-Talimaa, V. 1978. Telodonty silura i devona SSSR i Spitsbergena. Mokslas, Vilnius (in Russian). 
Karatajūtè-Talimaa, V. 1997. Taxonomy of loganiid thelodonts. Modern Geology, 21, 1-15.

Märss, T. \& Ritchie, A. 1998. Articulated thelodonts (Agnatha) of Scotland. Trans. Roy. Soc. Edinburgh: Earth Sci., 88, 143-195.

Märss, T. \& Gagnier, P.-Y. 2001. A new chondrichthyan from the Wenlock, Lower Silurian, of Baillie-Hamilton Island, the Canadian Arctic. J. Vert. Paleont., 21, 687-695.

Märss, T., Männik, P., Martma, T., Wilson, M. V. H., Caldwell, M. W., Thorsteinsson, R., Gagnier, P.-Y. \& Goujet, D. 1997. Distribution of Silurian vertebrate microremains in Baillie-Hamilton and Cornwallis Island sections, Arctic Canada. In Circum-Arctic Palaeozoic Vertebrates: Biological and Geological Significance. Buckow, Germany, July 4-6, 1997 (Wilson, M. V. H., ed.). Icht. Iss. Spec. Publ., 2, 20-22.

Märss, T., Caldwell, M., Gagnier, P.-Y., Goujet, D., Männik, P., Martma, T. \& Wilson, M. 1998a. Distribution of Silurian and Lower Devonian vertebrate microremains and conodonts in the Baillie-Hamilton and Cornwallis Island sections, Canadian Arctic. Proc. Estonian Acad. Sci. Geol., 47, 51-76.

Märss, T., Caldwell, M., Gagnier, P.-Y., Goujet, D., Männik, P., Martma, T. \& Wilson, M. 1998b. Results of the expedition to Baillie-Hamilton and Cornwallis Island in 1994. In Proceedings of the Sixth International Graptolite Conference of the GWG (IPA) and the SW Iberia Field Meeting 1998 of the International Subcommission on Silurian Stratigraphy (ICS-IUGS), Madrid, 1998 (Gutierres-Marco, J. \& Rabano, I., eds.), p. 104. Madrid.

Märss, T., Soehn, K. L. \& Wilson, M. V. H. 1998c. Microvertebrate-based correlations of the Llandovery-Wenlock boundary in some sections of the Selwyn and Franklinian sedimentary basins, northern Canada. In Circum-Arctic Palaeozoic Faunas and Facies. Warsaw, Poland, September 3-8, 1998 (Ginter, M. \& Wilson, M. V. H., eds.). Icht. Iss. Spec. Publ., 4, 37-39.

Märss, T., Soehn, K. L. \& Wilson, M. V. H. 1999. Event levels in the distribution of Silurian and Lower Devonian vertebrates in northern Canada. In Lower-Middle Palaeozoic Events Across the Circum-Arctic. Jürmala, Latvia, September 27-October 2, 1999 (Lukševičs, E., Stinkulis, G. \& Wilson, M. V. H., eds.). Icht. Iss. Spec. Publ., 5, 29-30.

Soehn, K. L., Märss, T., Caldwell, M. W. \& Wilson, M. V. H. 2001. New and biostratigraphically useful thelodonts from the Silurian of the Mackenzie Mountains, Northwest Territories, Canada. J. Vert. Paleont., 21, 651-659.

Turner, S. 1982. A new articulated thelodont (Agnatha) from the Early Devonian of Britain. Palaeontology, 25, 879-889.

Turner, S. 1991. Monophyly and interrelationships of the Thelodonti. In Early Vertebrates and Related Problems of Evolutionary Biology (Chang Mee-mann, Liu Yu-hai \& Zhang Guorui, eds.), pp. 87-119. Science Press, Beijing.

Turner, S. \& Peel, J. S. 1986. Silurian thelodont scales from North Greenland. Grønlands Geol. Unders. Rapport, 132, 79-88.

Vieth, J. 1980. Thelodontier-, Acanthodier- und Elasmobranchier-Schuppen aus dem Unter-Devon der Kanadischen Arktis (Agnatha, Pisces). Göttinger Arb. Geol. Paläont., 23, 1-69.

Wilson, M. V. H. \& Caldwell, M. W. 1998. The Furcacaudiformes: a new order of jawless vertebrates with thelodont scales, based on articulated Silurian and Devonian fossils from Northern Canada. J. Vert. Paleont., 18, 10-29.

Wilson, M. V. H., Thorsteinsson, R. \& Märss, T. 2000. Articulated thelodonts from the Lower Wenlock (Lower Silurian) of the Cape Phillips Formation, Canadian Arctic Archipelago. In 9th Annual International Symposium "Early Vertebrates/Lower Vertebrates". Flagstaff, Arizona, May 16th-19th, 2000 (Elliott, D. ed.), p. 22. Flagstaff. 


\title{
Uued telodontide (Agnatha) ja võimalike kõhrkalade (Gnathostomata) taksonid Kanada Arktika Silurist ja Alam-Devonist
}

\author{
Tiiu Märss, Mark V. H. Wilson ja Raymond Thorsteinsson
}

Lühidalt on käsitletud Baillie-Hamiltoni, Cornwallise, Walesi Printsi ja Devoni saare Silurist ja Alam-Devonist leitud eksemplaride põhjal püstitatud uusi varajaste selgroogsete taksoneid. Toodud on diagnoosid ja tüüpide andmed 25 uue telodondiliigi, 10 uue perekonna ja kuue uue sugukonna ning ühe seltsi kohta, aga ka võimalike kõhrkalade kahe uue liigi, kahe perekonna ja ühe sugukonna kohta. Materjali, sealhulgas nende varajaste selgroogsete kehakuju ja soomuste morfoloogiliste variatsioonide täielik kirjeldus on antud lähiajal trükki suunatavas monograafias.

\section{Новые таксоны телодонтов (Agnatha) и предполагаемых хрящевых рыб (Gnathostomata), установленные в силуре и нижнем девоне Канадской Арктики}

\section{Тийу Мярсс, Марк В. Х. Уильсон и Раймонд Тхорстейнссон}

Коротко рассмотрены новые таксоны ранних позвоночных, установленные на силурийском и нижнедевонском материале о-вов БейллиГамильтон, Корнуоллис, Принца Уэльского и Девона Канадской Арктики. Приведены диагнозы, данные по голотипам и иллюстрации по 25 новым видам, 10 родам, шести семействам и одному отряду телодонтов, а также по двум видам, двум родам и одному семейству предполагаемых хрящевых рыб. Полное описание материала, включая форму тела и вариации чешуй в чешуйных покровах, дается в подготовленной к печати монографии. 